\title{
Simone de Beauvoir
}

\section{STAROST \\ 1. Stališče zunanjosti \\ Ljubljana, OPRO - Zavod za aplikativne študije, 2018}

\section{Monografija Starost celostno obravnava starost, danes osrednje družbeno vprašanje}

Delo Simone de Beauvoir zajema vrsto romanov, obsežen skupek prijetno berljivih zapisov o Parizu in času, ko so Francozi še slavili svojo kulturo, svoje pisatelje in svoje intelektualce. Toda avtorica monografije Starost je prepričana, da intelektualci pač niso intelektualci, če ne presežejo interesov svojega družbenega razreda in se ne posvetijo skupnosti. Da je sama temu vodilu sledila, se je najprej izkazalo z objavo njene odmevne monografije Drugi spol (1947). »Ženska se ne rodi, ženska to šele postane, « je zapisala v ilustracijo vpliva družbe na posameznika ter koncepta družbenokulturnega spola. ${ }^{1}$

»Človek se ne rodi star, star postaja in postane, « bi po analogiji lahko dejali za njeno drugo prelomno monografijo Starost ali esej o starosti, kot ga sama imenuje. Prva ga je pred skoraj 50 leti objavila pariška založba Gallimard (1970), v nekdanji skupni Jugoslaviji nam je bila dosegljiva v izdaji beograjske založbe BIGZ (1986). Starost sem tako zdaj prebrala vnovič z večje kritične razdalje in zanesljivo trdim, da delo v družbi globalnega kapitalizma ni izgubilo svoje aktualnosti. Prav nasprotno!

Simone de Beauvoir zanimajo ne le posameznik, ki se stara, marveč in predvsem družbena določila staranja in starosti skozi zgodovino, v njeni in naši porabniški družbi, razmerje med starajočim se posameznikom in družbo. Ob branju monografije pa postane očitno, da se od antike sèm ni kaj dosti spremenilo. V vseh obdobjih so bili stari izgnanci iz družbe, trdi Simone de Beauvoir. Podobno pravi tudi Corvisier: »Naj spregovorijo vsi, tudi tisti, ki jim je petdeset let« so besede, s katerimi so na agori vabili svobodnjake, naj spregovorijo o javnih rečeh. ${ }^{2}$ Členek tudi se je ohranil vse do današnjih dni in kaže, da starejši danes, tako kot nekoč, niso pripuščeni k odločanju o javnih rečeh. Podobno kot danes so tudi nekoč v antični Grčiji pri starosti 60 let starim odvzeli ključne javne funkcije sodnikov, vojakov, arbitrov in jim v zameno prepustili zgolj, denimo, varovanje ozemlja

1 De Beauvoir, S. (1968). The Second Sex. New York: Modern Library.

2 Corvisier, J. N. La vieillesse dans le monde antique : aspects démographiques et conséquences sociales (https://journals.openedition.org/etudesanciennes/1032). 
ali utrjevanje utrdb. Razumljivo, kajti položaj mladih in starih zmeraj določajo generacije na sredi, tiste »merodajne«, ki jemljejo mero vsem drugim.

Človeka, kot smo že videli, ni mogoče obravnati z vidika ene same vede, še posebno ne človeka z družbenega roba. Podobno kot so približno v istem času ravnali tudi nekateri slovenski avtorji, je avtorica monografije Starost spoznanja o staranju in starih črpala iz vsega, kar ji je bilo na dosegu roke: umetnosti, filozofije, literature, sociologije, ekonomije. Virov, z izjemo del antične, klasične ruske ali francoske književnosti in medicinske literature, na temo starosti je bilo v nasprotju z današnjim časom malo. Celo psihologija staranja je bila zgolj v povojih. Avtorica pa razlaga človečnost zgodovinsko in antropološko, $\mathrm{z}$ vidika marksizma in fenomeologije.

Čeprav sta danes starost in staranje pogosta, celo modna tema, pa se zdi, da ob Starosti še zmeraj ni drugega podobnega dela, ki bi celostno obravnavalo vprašanje z biološkega in družbenega vidika hkrati, skozi zgodovino in v primežu družbenih sprememb, pojavov in paradoksov. Starejši so začuda svojo vlogo zmeraj sprejeli. Danes pa bi se resnično morali upreti političnim in drugim diskurzom o slabotnosti in odvisnosti, a to ne bo mogoče, če se ne bodo ovedeli svojega vsiljenega jim položaja in če ne bodo sami pripomogli k temu, da se ta spremeni. Odnos do starih je v porabniški družbi po mnenju Simone de Beauvoir stranpot civilizacije. Ni nujno, da takšen tudi ostane!

Simone de Beauvoir najprej govori o biološkem staranju. Gube se poglobijo, razmerja obraza se spremenijo, lasje se stanjšajo, upočasnijo se presnovni procesi. Nato piše o načinu življenja, o vplivu družbe na staranje, starost in stare. Težnja vsake družbe je, da preživi, poudarja, zato poveličuje moč in mladost ter se boji uničujoče sterilnosti. Tudi zato je nekoč veljalo, da je vodje, ki ostarijo, treba čim prej odstraniti in jih zamenjati, da bo skupnost varna. Starce so tako v zgodovini obredno fizično usmrtili ali pa so se ubili sami, danes pa jim fizično smrt preprečujemo, a jih prepuščamo socialni smrti, ko jim otežimo vstop v javnost, ko jim z zakoni otežimo delo, ker jih ne slišimo ali jih slabo slišimo. Starost je bila dolgo zgolj priprava na smrt in ne obdobje življenja! Tudi danes naj bi bilo tako, le da se danes smrti ne omenja. Celo na univerzi za tretje življenjsko obdobje se te teme na željo študentov ogibamo.

Simone de Beauvoir v prvem delu monografije navaja številne citate, ki slikajo odpor do fizičnega staranja: starost je upad, je grdota, je smrad. Še več! Starost so dolgo obravnali kot čas, podoben otroštvu, piše Simone de Beauvoir. Kako naj danes s tako preteklostjo, zapisano v našem kolektivnem spominu, starost vidimo drugače in kako naj delujemo drugače? V današnjih družbah, opozarja avtorica, se starejšim ne posvečamo, četudi s tem zanemarjamo svojo lastno prihodnost.

Delo Starost je danes še bolj aktualno, kot je bilo ob svojem nastanku. Razkriva korenine našega razmišljanja in ravnanja in tudi tako bi ga veljalo brati; s svinčnikom v roki, v nenehnem iskanju podobnosti in razlik med preteklim in sodobnim časom ter $\mathrm{v}$ iskanju boljših odgovorov in rešitev. Danes je - in jutri bo - starost lahko drugačna, a potrebni so ozaveščenost, vednost, znanje, upor in delovanje. Morda se bo sprememba zgodila, ker 
starci nismo več redki kot nekoč, ker bomo morali prevzeti odgovornost za skupno prihodnost generacij. Branje dela Starost je zagotovo vreden korak na tej poti.

Dušana Findeisen 